\title{
The Moderating Role of Bridging Ties between Risk-Taking, Proactivness and Performance: The Evidence from Iranian SMEs
}

\author{
Alireza Jalali ${ }^{1}$, Mastura Jaafar ${ }^{1}$, Kambiz Talebi $^{2} \&$ Suberi Ab Halim ${ }^{3}$ \\ ${ }^{1}$ School of Housing Building and Planning, University Sains Malaysia, Penang, Malaysia \\ ${ }^{2}$ School of Entrepreneurship, University of Tehran, Tehran, Iran \\ ${ }^{3}$ School of Business Innovation and Technology, University Malaysia Perlis, Perlis, Malaysia \\ Correspondence: Alireza Jalali, E-22-05 Sunny ville condominium, Jalan Batu Oban, Gelugor, Penang, Malaysia. \\ Tel: 601-7430-1730. E-mail: arjiaa@yahoo.com
}

Received: December 4, 2013

Accepted: February 23, $2014 \quad$ Online Published: April 18, 2014

doi:10.5539/ijbm.v9n5p74

URL: http://dx.doi.org/10.5539/ijbm.v9n5p74

\begin{abstract}
This study explores the interaction effect of bridging ties by looking at the relationship between proactiveness, risk-taking, and performance. A questionnaire was administered to 150 manufacturing Small and Medium Enterprises (SMEs) in Iran. A model relating proactiveness and risk-taking to performance with the moderating role of bridging ties was tested using Statistical Package for the Social Sciences (SPSS) and the results proved significant. Our results indicate a positive relationship between proactiveness, risk-taking and performance. The main contribution of this study resides in addressing the significance of firm performance as a dependent variable deserving of more attention in the field of entrepreneurship and networking.
\end{abstract}

Keyword: risk-taking, proactiveness, bridging ties, SMEs, Iran

\section{Introduction}

Small and medium enterprises (SMEs) have solicited the consideration of many researchers regarding its role in providing employment, poverty reduction and motivating economic improvement opportunities (Talebi, Tajeddin, Rastegar, \& Emami, 2012). Jalali, Jafaar, and Ramayah (2014) argued that SMEs concentrating on meeting client requirements can successfully enter the universal market. SMEs play an important role in most developed countries such as the USA and the UK, and account for one third of industrial employment (Smit \& Watkins, 2012). In Switzerland, there are almost 300,000 SMEs comprising close to $95 \%$ of active firms (Tajeddini \& Mueller, 2009). In developing countries where SMEs contain economically dynamic enterprises, the SMEs' achievements are far more significant than in developed countries (Jalali, Jafaar, \& Ramayah, 2013; Rwigema \& Karungu, 1999). In one developing country, The Philippines, SMEs provide almost $70 \%$ of the country's total employment and 30\% of the country gross domestic product (GDP) (Roxas \& Chadee, 2012).

Likewise, SMEs account for approximately $75 \%$ of all the Iranian firms where $63 \%$ of the workforce is employed in the private sector. Overall, SMEs contribute the value-added of approximately $30 \%$ (Jalali et al., 2014). SMEs in Iran are defined as micro enterprises with 1-9 employees, small enterprises with 10-49 employees, and medium enterprises with 50-99 employees (Jalali et al., 2013). According to Talebi and Tajeddin (2011), Iranian public policy is interested in SMEs because of the latter's function in elevating flexibility and innovation and in creating jobs as well as their powerless role in employment despite the huge size of the sector in comparison with large enterprises. Jalali et al. (2013) argued that Iranian SMEs experience chronic problems with having insufficient funds, traditional structures in different aspect of the organizational hierarchy, human power and technology, inexperienced managers and employees, and a lack of entrepreneurial abilities and orientation.

By emphasizing the resource-based view (RVB), a study was conducted on the Iranian speculative SMEs to peruse the precious know-how required to succeed. An RBV concentrates on a firm's tangible and intangible resources, thereby providing insight into a firm's competitiveness to develop unique products for niche markets (Terziovski, 2010). Cohen and Kaimenakis (2007) argued that few studies have investigated intangible resources, such as proactiveness, risk-taking and bridging ties in SMEs. SMEs, compared to larger firms, expand their ties as a significant intangible resource with greater ease and use the knowledge from their associations more readily 
in order to achieve higher performance (Desouza \& Awazu, 2006). In the same manner, Wong and Aspinwall (2004) argue that SMEs' close proximity to other firms enables them to acquire knowledge more readily compared to larger firms.

The "external social capital" that bridging ties beyond networks is beneficial to firm performance (Klyver \& Schenkel, 2013). A superior understanding of the conditions, in which proactiveness and risk-taking enhances firm performance, requires a contingency perspective that emphasizes the importance of fit in the firm's strategic posture and other constructs of interest (Lumpkin \& Dess, 1996). Therefore, the current study aims to determine how social capital embedded in bridging ties affects the relationship between proactiveness, risk-taking and firm performance. This paper identifies bridging ties, in exploring the impacts of relationships, networks, and reputation on the creation and subsequent development of SMEs.

Most SME studies in Iran have focused only on innovative strategies (e.g., Kamalian, Rashki, \& Arbabi, 2011; Maatoofi \& Tajeddinni, 2011; Talebi \& Tajeddin, 2011) and the role of IT (e.g., Sanayei \& Rajabion, 2012, Talebi et al., 2012). The impact of proactiveness and risk taking on the performance of SMEs in Iran remains unclear. This study attempts to fill this gap by focusing on these two variables.

Given that very few studies have been conducted in relation to this topic in Iran, there is a knowledge gap in the literature concerning with regards proactiveness and risk-taking. Thus, the first objective of this study is to investigate the relationships between the proactiveness, risk-taking and firm performance. The second objective is to investigate the effect of bridging ties as a moderator of proactivness, risk-taking and SME performance. The paper is structured as follows: Section 2 characterizes the basic concepts of the paper and reviews relevant literature; a description of the methodology follows in Section 3, Section 4 presents the basic findings; and Section 5 summarizes the results along with their implications.

\section{Literature Review}

\subsection{Resource-based View (RBV) and Social Capital Theory as Underpinning Theories}

Resources can be tangible or intangible in nature. Tangible resources include capital and access to capital and location, among others, while intangible resources consist of knowledge, skills and reputation, entrepreneurial orientation, and so on (Perrigot, López-Fernández, \& Eroglu, 2013). The RBV suggests that differences in performance among firms are best explained through differences in firm resources including their accumulation and usage (Lockett, Thompson, \& Morgenstern, 2009; Peteraf, 1993). Different kinds of resources contribute toward firm performance. Peteraf (1993) reports that one major contribution of RBV is explaining long-term differences in firm profitability and performance, which cannot be attributed to the variations in the industry conditions. Recent evidence suggests a relationship between organizational performance and intangible assets, which comprise of the firm's human capital (Perrigot et al., 2013), social capital-organizational or individual networks, organizational capital and capabilities (Meihami, Varmaghani, \& Meihami, 2014; Zahra, 2010), and accessible financial capital (Cooper, Gimeno-Gascon, \& Woo, 1994; Robb \& Robinson, 2014).

The pattern of social capital in meliorate entrepreneurship is confirmed by the literature. For example, Aldrich and Martinez (2010) and Audretch and Keibach (2004) argued that social capital play a significant role in entrepreneurship. Such a link between social capital and performance is supported by empirical research (Meihami et al., 2014; Putnam, 2000). The social capital perspective posits that network ties can help small and medium firms improve their knowledge and give them access to different types of recourses, which can promote innovation (Batjargal, 2007; Lechner \& Dowling, 2003; Zahra, 2010). Hence, social capital builds networks among individuals within an industry and between firms and organizations outside the industry; furthermore, different kinds of resources can be concluded from these networks (Hessels, 2008; Zahra, 2010).

\subsection{Proactiveness and Performance}

Proactiveness is defined as acting to shape the environment by influencing trends, developing demand, and becoming a leader among competitors (Craig, Pohjola, Kraus, \& Jensen, 2014; Lumpkin \& Dess, 1996). In a rapidly transforming environment where both product and business models have very short lifecycles, future profits create from existing operations with ambiguity; thus, firms must constantly seekout new opportunities. The specifications on entrepreneurial firms must enable them to beat their competitors and be the first to come up with proactive creations (Craig et al., 2014; Jalali et al., 2013; Miller, 1983). This action has been characterized as strategic agility (Bullinger, 1999) and is similar to the concept of dynamic abilities as first proposed by Teece (2007). This is the capacity to sense weak signals and seize upon them with appropriate entrepreneurial investment behaviors. One recent study found that proactive small firms can develop competitive advantage by making initiatives, creating novel demands and markets, and by charging higher 
prices (Craig et al., 2014). Thus proactivness strategy is positively related to performance (Avalonitis \& Salavou, 2007).

Entrepreneurial proactiveness is a fundamental aspect of competitive advantage and innovation output (Brandle, 2001; Jalali et al., 2014). Proactive firms find more opportunities ahead of their competitors, create initiatives that give them advantages in the market, and charge higher prices than their rivals (Craig et al., 2014; Zahra \& Covin, 1995). Such firms can govern the market by capturing the dispensation channel and establishing brand recognition (Wiklund \& Shepherd, 2005).

\subsection{Risk-Taking and Performance}

Risk-taking is defined as the willingness to be bold and aggressive in pursuing opportunities, and in preferring high-risk projects with chances of very high returns over low-risk projects with lower and more predictable rates of return (Jalali et al., 2013; Katz \& Brockhaus, 1993). March (1991) and McGrath (2001) believed that firms with tried-and-true strategies lead to high mean performance, while risky ventures may lead to low mean performance, such projects may either fail or prosper over the long term. Kraus and Harms (2011) found that family firms prefer not to take risk or optimistically conservative to take risk. Accordingly, Craig et al. (2014) and Naldi et al. (2007) found a negative relationship between risk-taking and performance among Finnish family firms.

Despite the results of previous studies finding a negative relationship between risk-taking and performance, entrepreneurs generally accept that entrepreneurship involves risk-taking; thus, they are willing to take risks in return for potential rewards (Gebreegziabher \& Tadesse, 2014; Jalali et al., 2014; Segal, Borgia, \& Schoenfeld, 2005). Furthermore, Mc Clelland (1961) argues that entrepreneurs are more eager to take risks than non-entrepreneurs. Frese, Brantjes, and Hoorn (2002) argued that firms are likely to seize beneficial deals if they have a risk-taking orientation and risk-taking is positively related to success. In general, the links between risk-taking and performance is less obvious (Wiklund \& Shepherd, 2005).

\subsection{Interaction Effect of Bridging Ties}

Recent literature found that social capital has a positive impact on the relationship between proactiveness, risk-taking and firm performance (e.g., Anderson \& Eshima, 2011; Zhang \& Zhang, 2012). Bridging ties refers to the extent to which a firm establishes bonds outside of the central industry network, typically with organizations from other fields (Geletkanycz \& Hambrick, 1997). Bridged ties are unique and direct network bonds between two social circles, where no other direct or indirect ties connect the two groups (Granovetter, 1985; Zahra, 2010). A structural bridge is more likely to connect people with diverse perspectives, different outlooks, varying interests, and diverse approaches to problems (Arregle et al., 2007; Granovetter, 1985).

Such ties beyond the private industry are especially significant for firms with strong proactiveness and a risk-taking strategy. This is because they simplify achievements to complementary resources that are not achievable within industry boundaries, but are necessary for the entrepreneurial firms to access value from their strategies (Arregle et al., 2007; Teece, 1986). Product development can benefit from cooperative relations with organizations outside the industry such as research communities (Allen, 1977; Henderson \& Cockburn, 2006; Zahra, 2010). "An entrepreneur might be connected to a network that has high level of expertise in a particular technology and also be connected, unrelated network of actors inside the organization who have a problem that might be solved through application of the technology. By having a deep understanding of both the technology and the problem, the entrepreneur is able to see the potential of making new combination." (Low \& Abrahamson, 1997, pp. 443).

Thus, bridged bonds perform the role of a searching device, allowing entrepreneurial firms to rapidly identify new trends and incommensurability in a market as compared with other firms lacking such connections. Apart from providing access to pioneer resources, bridging ties permits firms to connect themselves with more prosperous and well-organized firms and institutions operating in their external environment (Stuart, Hoang, \& Hybels, 1999). Given that firms with strong proactiveness tend to be the first to introduce new products and services that significantly depart from existing offerings, they are in greater demand in building legitimacy for their innovations (Aldrich \& Fiol, 1994). Establishing various sets of bridging ties also allows entrepreneurial ventures to generate an understanding of their entrepreneurial innovative activities among exterior resource providers; increasing their legitimacy by "piggybacking" on the validity of these organizations from other industries (Starr \& MacMillan, 1990). Bridging ties with, for example, venture capitalists, the education sector, and the media enables entrepreneurial ventures to demonstrate their proportion with current norms and practices, facilitating access to precious resources that ensure firm growth and survival (Zimmerman \& Zeitz, 2002). 


\section{Research Methodology}

\subsection{Research Framework}

The above discussion provides a support for the conceptual framework below (Figure 1).

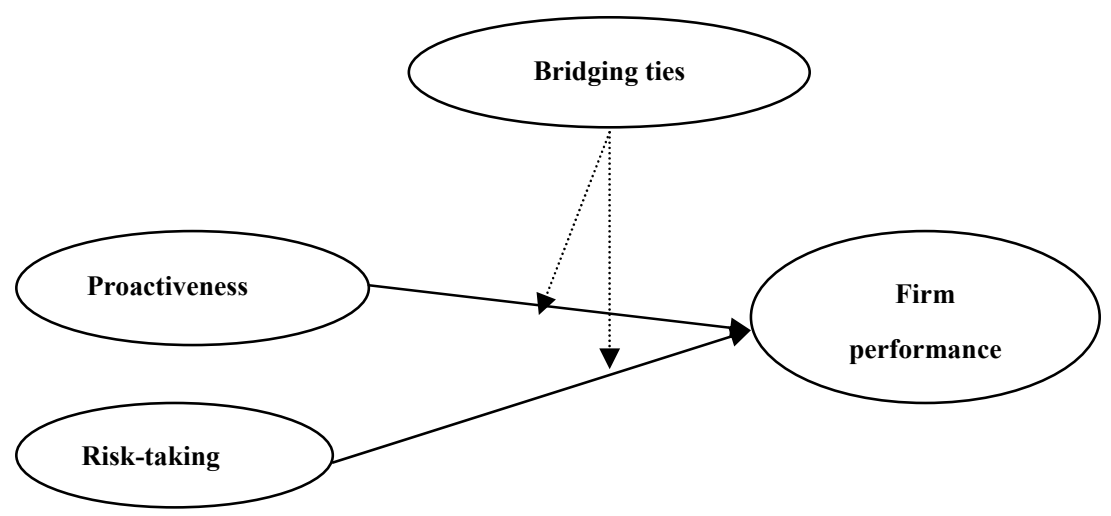

Figure 1. Conceptual frame work

In relation to the above, the two main hypotheses and respective sub-hypotheses are listed below.

$\mathrm{H} 1$ : proactiveness is positively related to the performance of SMEs.

H2: Risk-taking is positively related to the growth-profitability of SMEs.

$\mathrm{H} 3$ : Bridging ties moderated the relationship between proactiveness and firm performance.

H4: Bridging ties moderated the relationship between risk-taking and firm performance.

\subsection{Sample and Data Collection}

To test these hypotheses, a survey method was used to seek responses from various manufacturing SMEs in the Tehran and Isfahan provinces of Iran. These provinces were chosen because there are the first and the second largest provinces in Iran. Using a preliminary draft questionnaire, a pilot study was conducted with 20 firms from Tehran, whose responses were then excluded from the final study. The questionnaire was revised using the feedback from the pilot study goup and, in accordance with a sample frame provided by the 2008 Iran Statistical Year Book, which was created by a random sample of manufacturing enterprises.

The sample was cross-sectional. Face-to-face interviews with entrepreneurs were conducted in order to increase the questions' readability. A total of 580 enterprises were approached from March to September 2012, and 158 enterprises agreed to participate. After eliminating firms later liquidated, 150 firms were included in our analyses. Therefore, the effective response rate was $26 \%(150-580)$. One issue pertinent to survey methodology was nonresponse bias. Nonresponse bias exists where there are significant differences between the answers of respondents and nonrespondents (Lambert \& Harrington, 1990). We followed up with 422 nonresponding firms and compared their answers with those who responded to our survey using a t-test. All t-statistics were insignificant.

Similarly, we followed the convention of comparing the respondents of the second wave with those of the first wave along with all the survey items (Stanley \& Wisner, 2001) and did not find significant difference either. Finally, we split the final sample into two groups, depending on the dates completed survey were received. The early wave group consisted of 67 respondents; whereas the late wave group consisted of 83 respondents. The t-tests performed on the responses of these two groups yielded no statistically significant differences on demographic characteristics with a $99 \%$ confidence interval. We thus concluded that there was no significant nonresponse bias in this study.

\section{Analysis}

Hierarchical moderated regression analysis was used to test our hypotheses. This method is suitable to determine the effect of the moderating variable. According to Jaccard and Turrist (2003) the moderating effect exists if the variance explained in the criterion is higher for the model with interaction effect. West and Aiken (1991) emphasized on the important role of the predictor variables to build and interaction terms. Furthermore several regression diagnostics were used for all the models in order to determine where or not the assumptions for 
normality and multicollinearity problems were satisfied.

\subsection{Measures}

To measure proactiveness and risk-taking, we used an eight item 'EO' scale (Covin \& Slevin, 1989; Naldi et al., 2007). For risk taking, we also add three items, based on self-efficacy theory (Bandura, 1977), which measure an individual's belief that he or she is capable of mobilizing "the motivation, cognitive resources, and courses of action needed to exercise control over events in their lives" (Wood \& Bandura, 1989, p.364). In according with the study of Davidsson (1989), compose dimensions, namely, growth-profitability, were used to measure firm performance. Growth focuses on the increase in sales and increased profits compared with competitors. In the current study, the percentage growth in total sales over the past three years, labeled "sales growth rate"), and the percentage growth in profit over the same period, labeled as "profit growth rate", were used (Khatri, 2000). The response ranges (i.e., from $1=10 \%-20 \%$ to $8=90 \%-100 \%$ growth scores) were calculated; higher scores representing better growth. The respondents were asked to evaluate their firm's performance using financial information. The managerial ties scale created by Peng and Luo (2000) was used. This scale is recognized as a valid and reliable indicator of the extent to which a firm develops personal ties to organizations outside the industry. We provided the entrepreneurs with a list of 14 varieties of organizations, which were distilled from the professional questionnaires and expected to be significant sources of information and legitimacy for SMEs. Examples of organizations included in the list were industry association, health institutes, media, special training centers, political parties, and financial institutes, among others. The respondents were also requested to indicate the extent to which the owner of the firm created personal relations with each type of organization. The scores ranged from 1 ("very low relation") to 5 ("very high relation").

\subsection{Validity and Reliability}

Principal component analysis (PCA) of the proactiveness and risk-taking items (see Table 1) resulted in two components accounting for $74 \%$ of the variance in the items. The items measured proactiveness in the first component and risk-taking in the second component. The internal consistency of the scales was good. Proactiveness and risk-taking, had Cronbach's alpha values of 0.900 and 0.915 respectively.

Table 1. Principal component loadings of the proactiveness and risk-taking items

\begin{tabular}{lcc}
\hline Item & PC & RC \\
\hline Proactiveness (PC) & .607 & .162 \\
Identify new markets according to the customer demands related to the current products or services & .741 & .180 \\
Try to find new technology for finalizing the farmer knowledge related to sale techniques and relation with other & .700 & .232 \\
sellers or marketing of new products or services & .878 & .050 \\
Takes on a very competitive oriented "beat-the-competitor" position & .937 & .065 \\
Our company is very often the first company to introduce new products or services & .835 & .069 \\
Our company is very often the first company to introduce new administrative systems, methods of production etc. & \\
Normally we react upon initiatives taken by our competitors and initiate changes upon which our competitors react. & .205 \\
Risk Taking (RC) & .911 \\
A strong tendency toward getting involved in high risk projects (with a chance for high yield) & .114 \\
Start a business without adequate human resources & .703 \\
Live with uncertainty from return on investment & -.010 \\
Live in high competitive risk environment (the speed of product to be saturated in the market and enduring against & .847 \\
competitors) & .196 \\
Endurance against market risk (number of customers greeting the new products or services) & .932 \\
Eigenvalues Value & .146 \\
Total Variance (73.84\%) & .858 \\
\hline
\end{tabular}

Principal Component Analysis with Varimax rotation. KMO measure of sampling adequacy $=.786$.

PCA of the performance items (see Table 2) resulted in one component accounting for $64 \%$ of the variance in the items. The internal consistency was satisfactory (Cronbach's alpha $=0.712$ ). 
Table 2. Principal component loading of Firm performance

\begin{tabular}{lcc}
\hline Item & Loadings \\
\hline Increase in average profitability from total sales in the last 3 years & FM1 & .879 \\
Increase in total sales in the last 3 years & FM2 & .889 \\
Increase in profitability in relation to your competitors' profitability in the last 3 years & FM3 & .609 \\
Eigenvalues Value & 1.934 \\
Total Variance & $64.47 \%$ \\
\hline
\end{tabular}

Principal Component Analysis with Varimax rotation. KMO measure of sampling adequacy $=.587$.

The PCA of items pertaining to bridging ties (see Table 3) resulted in one component accounting for $76 \%$ of the variance in the items. The internal consistency was satisfactory (Cronbach's alpha $=0.969$ ).

Table 3. Principal component loading of the bridging ties items

\begin{tabular}{ll}
\hline Items & $\begin{array}{l}\text { Factor } \\
\text { ties }\end{array}$ \\
\hline bridging ties & .905 \\
Industry association & .899 \\
Health institutes & .819 \\
Political parties/ Government & .898 \\
Specialized training and education centres & .841 \\
Media (e.g. newspaper, radio, television) & .832 \\
Foreign companies & 0.936 \\
The incubators (e.g. companies that assist in networking, marketing, high speed & .810 \\
internet access, access to bank loans and funds, guarantee programmes, etc.) & .753 \\
Open source software communities (i.e. focused on improving technical transfers & .877 \\
between companies, generating social networks for collaboration among them)/ IT & .629 \\
company & .887 \\
Law firms & .883 \\
Financial institutions & .888 \\
Research institutions/ Universities & 4.933 \\
Foreign open source organisations & $76.27 \%$ \\
Educational associations & \\
Transport Industry & \\
Eigenvalues Value & \\
Total Variance & \\
\hline
\end{tabular}

\section{Results}

Descriptive analysis showed the highest rate of proactiveness among respondents $(\mathrm{m}=4.53, \mathrm{SD}=0.66)$, and risk-taking $(\mathrm{m}=3.57, \mathrm{SD}=0.89)$. Based on the results of the descriptive analysis, most entrepreneurs in Iran thought that they possessed both proactiveness and risk-taking characteristics (see Table 4). This result was supported by Aloulou and Fayolle (2005), who found that the entrepreneurs or top managers of entrepreneurial firms possess both proactive and risk-taking characteristics. A Pearson correlation was performed to investigate the inter-correlation among the continuous variables (see Table 5). All of the variables showed significant correlation with firm performance. A medium correlation was observed between proactiveness and firm performance $(r=0.482 ; p<0.01)$ and between risk taking and firm performance $(r=0.480 ; p<0.01)$. Based on the analysis, the correlations among variables fell within the acceptable range $(<0.80)$. No multicollinearity issues were noted in this study. 
Table 4. Descriptive statistics

\begin{tabular}{lcc}
\hline Item & Mean & Std. Deviation \\
\hline Proactiveness & 4.53 & .66 \\
Risk taking & 3.57 & .89 \\
Bridging-ties & 3.62 & .82 \\
Firm performance & 3.92 & .85 \\
\hline
\end{tabular}

Table 5. Correlation analysis

\begin{tabular}{lllll}
\hline & proactiveness & Risk-taking & Bridging ties & FM \\
\hline FM Proactiveness (PC) & 1.000 & & & \\
Risk taking (RC) & $.299^{* *}$ & 1.000 & & \\
Bridging ties & $.378^{* *}$ & $.048^{* *}$ & 1.000 & \\
Firm performance (FM) & $.482^{* *}$ & $.480^{* *}$ & $.597^{* *}$ & 1.000 \\
\hline
\end{tabular}

Note. ${ }^{* *} \mathrm{P}<0.01$.

The hypotheses were tested using hierarchical regression analysis. Table 6 shows the moderating effects of bridging ties on the relationship between proactiveness, risk-taking and firm performance. This analysis consisted of three models. In Model 1 , proactiveness $(\beta=0.250$; t-value $=3.418 ; \mathrm{p}<0.001)$ and risk taking $(\beta=$ $0.351 ; \mathrm{t}$-value $=5.293 ; \mathrm{p}<0.001)$ all have positively significant correlations with firm performance. Thus, H1 and $\mathrm{H} 2$ were supported. Risk-taking $(\beta=0.351)$ had the strongest positive relationship with growth-profitability, whereas the other proactiveness $(\beta=0.250)$ had a weaker relationship (Table 6). Furthermore, the model accounted for $(\mathrm{R} 2=0.417) 41.7 \%$ of the variance of growth-profitability. Model 2 concerns the inclusion of the moderating variable, with the model being significant $(F=27.597, \mathrm{p}<0.001)$ and the $\mathrm{R} 2$ value denoting $43.2 \%$ of the variance being accounted for. Model 3 shows the results for the interaction effect of the moderating variable (bridging ties) and the independent variables, proactiveness and risk-taking, on the dependent variable (i.e., firm performance). This was done by including the interaction effects of bridging ties between proactiveness, risk-taking and firm performance. The model was found significant $(F$ value $=20.770, p<0.001)$, wherein the R2 value accounts for $48.2 \%$ of the variance, with $48.2 \%$ being attributed to the interaction terms. The interactive effects of bridging ties and proactiveness on growth-profitability was significant, as shown in Model 3 of Table 6; thus $\mathrm{H} 3$ was supported. However, the interactive effect of bridging ties and risk-taking were not statistically significant; thus, $\mathrm{H} 4$ were not supported.

Table 6. Results of interaction effect of bridging ties on relationship between proactiveness, risk-taking and firm performance

\begin{tabular}{lllll}
\hline IV & Model 1 & Model 2 & Model 3 \\
\hline Proactiveness (PC) & $.250^{* * *}$ & $.194^{*}$ & $1.271^{*}$ \\
Risk taking (RC) & $.351^{* * *}$ & $.361^{* * *}$ & .608 \\
Moderator & & & \\
bridging ties & & $.135^{*}$ & $2.071^{* * *}$ \\
Interaction & & & \\
PC* bridging ties & & & $-2.339 * * *$ \\
$\mathrm{RC}^{*}$ bridging ties & & & -.343 \\
$\mathrm{R}^{2}$ & .417 & .432 & .506 \\
$\mathrm{Adjusted} \mathrm{R}^{2}$ & .405 & .417 & .482 \\
$\mathrm{R}^{2}$ Change & .417 & .015 & .074 \\
$\mathrm{~F}$ & $34.777^{* * *}$ & $27.597 * * *$ & $20.770^{* * *}$ \\
$\mathrm{~F}$ Change & 34.777 & 3.949 & 7.057 \\
\hline
\end{tabular}

Note. ${ }^{*} \mathrm{p}<0.05,{ }^{* *} \mathrm{p}<0.01,{ }^{* * *} \mathrm{p}<0.001$.

\subsection{Simple Slope of the Moderating Effect of Bridging Ties}

The plot line of bridging ties and the independent variable (proactiveness) shows a pattern consistent with that of the dependent variable (firm performance). 


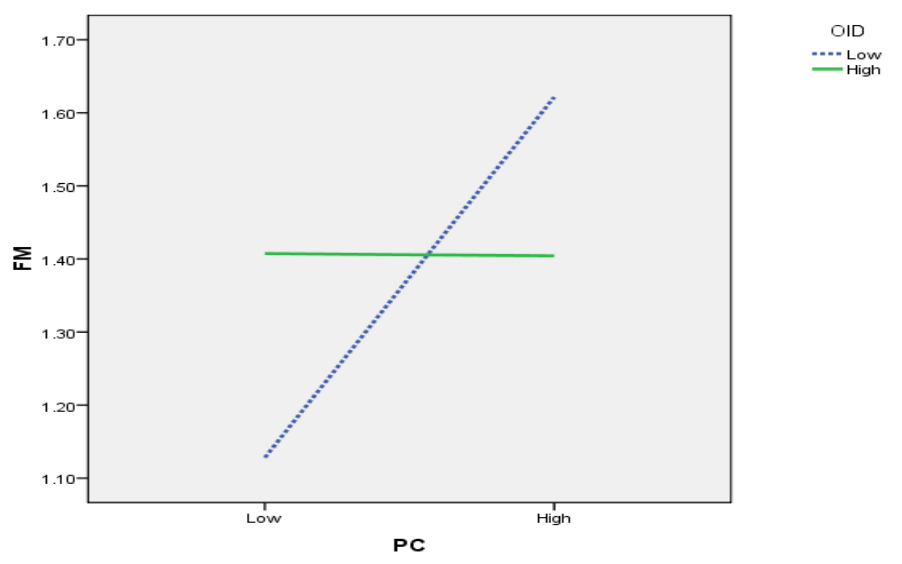

Figure 2. The interaction graph between bridging ties and proactiveness

Bridging ties moderated the effect of proactiveness on firm performance, which was stronger for low bridging ties, and showed no effect in the case of high bridging ties (see Figure 2). This stronger relationship is indicated by the slope of the low bridging ties compared with the slope of high bridging ties. Companies with low levels of bridging ties reported significantly higher levels of proactiveness.

\section{Discussion and Conclusion}

Descriptive analysis showed the highest rate of proactiveness $(\mathrm{m}=4.53, \mathrm{SD}=0.66)$ and risk-taking $(\mathrm{m}=3.57$, $\mathrm{SD}=0.89$ ) among respondents. A high rate of competitiveness with established players is likely result in failure because of the lack of proactiveness and risk-taking strategies among Iranian SMEs.

The result for proactiveness support previous studies by Zahra and Covin (1995), Brendle (2001) and Wiklund and Shepherd (2005), who argued that proactive companies can develop competitive advantage by being innovators, targeting new demands and markets, and by charging high prices. Due to the large number of manufacturing SMEs in Iran, there are certain if advantages in being the first business going into a market. Firstly, it can capture the market share more quickly without having to worry about competitors trying to capture identical customers. Secondly, when competitors do advance, as they inevitably will, the first mover and its operation team will have an advantage in the ensuing competition, such as having more familiar products and brand loyalty. The advantage of being proactive must, however, is solidified with resources. Money, human resources and knowledge are needed to insure these advantages will be maintained.

In terms of risk-taking, the results of this study conflict with those of previous studies. Naldi et al. (2007), found that there is a negative relationship between risk-taking and family firm performance and that there is a positive relationship between risk-taking and performance among Iranian SMEs. Our results do, however, support previous studies reporting that risk-taking strategy is significantly positively related to higher variability in profitability (Frese et al., 2002; Rauch et al., 2009; Soininen et al., 2012). Risk-taking enables Iranian SMEs to commit resources to ventures in uncertain environments that can lead them into international markets. Due to the changes in international environment and the necessity of integration in the international market, Iran needs to consider increasing its non-oil exports in order to become an active partner in the WTO-led globalization process.

On the other hand, although the principles of risk are pervasive throughout all kinds of enterprises, the usage risk-taking varies considerably among small and large enterprises. Many SMEs practice risk management when they estimate risks in the decision-making process (Ntlhane, 1995). In the risk-taking process, Iranian entrepreneurs should be aware that risk actions must be followed by some specific requirements of the enterprises, taking into account its resources, needs and prevailing opportunities. Thus, political decision-makers responsible for economic policy should consider ways by which to create incentives supporting SMEs engaged in growth actions with high risk-taking characteristics.

A moderating variable affects the direction and/or strength of the relationship between an independent and dependent variable (Baron \& Kenny, 1986, p. 1173). Table 6 and Figure 1 show the results for the interaction effect of bridging ties on the relationship between proactiveness and firm performance. The model was found significant $(\mathrm{F}=20.770, \mathrm{p}<0.001)$, with the $\mathrm{R} 2$ value denoting $50.6 \%$ of the variance, $48.2 \%$ of which can be 
attributed to the interaction terms. Thus, organizations outside the industry have a moderating role on the independent variable (proactiveness) and the dependent variable (growth-profitability).

These results highlight the importance of other types of capital such as customer capital, manifested in Iranian firms units, and the necessity of the fit between customer capital and bridging ties which leads them to pursue both proactiveness and risk-taking (Lumpkin \& Dess, 1996). Jalali et al (2014) found that a firm's customer capital enables Iranian entrepreneurs to develop proactive and risk-taking capabilities resulting in greater profitability. Our results suggest that Iranian entrepreneurs who cultivate different type of ties simultaneously are more likely to perform better. Also, Iranian entrepreneurs should consider the nature of the external environment which has a significant role on the effectiveness of their managerial strategies (See Hitt, Bierman, Shimizu, \& Kochhar, 2000).

\section{Theoretical and Practical Implications}

This study revealed that high bridging ties weakened the relationship between proactiveness and growth-profitability (see Figure 2). One possible explanation for this relationship is the lack of adaptability between the firm's strategic position and the composition of environmental factors, which adversely impacts the relationship between entrepreneurial orientation and firm performance (Lumpkin \& Dess, 1996). Environmental factors, such as government financial aid and the protection of organizations outside the industry, can strain the relationship between Iranian SMEs and organizations outside the industry. Establishing extra ties between Iranian firms and external organizations can be expensive for Iranian manufacturing firms, and without government support they may not be able to create such ties. Another possible explanation is the contingent value of social capital (Ahuja, 2000). Maximum firm performance results from the combination of its quick and independent access to other firms in the particular industry network centrality and bridging ties. Creating relationships with other organizations outside the industry, without investing on networks, can adversely affect a firm's performance.

One unexpected outcome observed in this study was the lack of support for a moderating effect of bridging risk-taking and growth-profitability. This might be explained by the nature of the sample and measures used in this study. Given that risk-taking and bridging ties were found to be positively correlated, the outcome reflected limited variance in the bridging ties scores among SME manufacturing firms. Bridging ties in other types of industry networks may have a stronger moderating effect. Another possibility for the lack of moderation observed was our use of an aggregated measure of firm performance. Although supported by our factor analysis, an aggregated measure of firm performance might not be sensitive to the interactions between bridging ties and risk-taking (Lumpkin \& Dess, 2001). One final possibility for this observation is the weak risk-taking strategy among Iranian entrepreneurs. It is likely that Iranian entrepreneurs do not sustain bridged ties with organizations outside their industry. These bonds are particularly important for ventures with a strong risk-taking strategy because they facilitate access to complementary resources not ordinarily available within the industry boundaries (Teece, 1986). This would suggest that Iranian SME's likely rely on current technology and information, and are not motivated to establish relationships with organizations outside the industry, such as universities. Such joint industry bridges can facilitate the development of new routine competencies and technologies that would have resulted in network bridging ties that "bring together new combination of productive factors" (Low \& Amberson, 1997, p. 443).

This study contributes to the expanding body of entrepreneurship literature. We examined the composed dimension of firm performance based on the work of Cowling (2004), who have explicitly addressed the growth-profitability relationship as their main research question, unlike previous studies (e.g. Soininen et al., 2012). This study contributes toward improving our understanding of how proactiveness, risk-taking and bridging ties construct the performance of a firm (Aldrich \& Fiol, 1994). Rauch et al. (2009) observes that many of the earlier entrepreneurship studies concentrated on U.S. companies. In our view, Iran provides an interesting new setting for this kind of analysis, because it constitutes a good example of a competitive and innovative business environment. In addition, we utilized both RBV and social capital theory to explain firm performance. The theory of social capital emerged out of theories concerning social networks and shifted attention away from RBV-inspired questions of 'what you know' to 'who you know,' by taking stock of a firm's linkages with external networks. Furthermore, this study demonstrates how bridging ties channels form relationship between proactiveness and firm performance. Regarding to the high expense of bridging ties, the commitment of the government to support Iranian SMEs may be as important as the prominence of the partners which is suggested by Podolny (1993), to encourage entrepreneurs for bridging ties with industry outside the industry. 


\section{Limitations and Avenues for Future Research}

Nevertheless, our study did have its limitations. Firstly, we were entrepreneur-centric. We assumed that the entrepreneur was the determining figure behind the success of an enterprise. Obviously this assumption fails to include the myriad of other possible arrangements that characterize SMEs in Iran. SMEs operating without a dominant player or that are owned and managed by a team of entrepreneurs were unwittingly excluded, although the impact of having a team of owner-managers was addressed indirectly through the organizational structure and linkages variables. Moreover, our sample involved several young ventures, for which performance indicators might not always be appropriate (Zahra, 1996). The pattern of the results also revealed a problem with the use aggregated performance measurements which can hide significant indirect effects of a firm's resources on lower level processes (Ray et al., 2004). Future studies, therefore, should utilize more suitable performance measures that can better capture the effectiveness of a venture's key business process. Finally, the performance dimensions were comprised of a variety of performance-relevant specifications and might have been better illustrated by a formative construct (See Becker, Klein, \& Wetzels, 2012). Future research might better measure performance by using a formative construct.

\section{References}

Acs, Z. J., \& Preston, L. (1997). Small and Medium-Sized Enterprises, Technology, and Globalization: Introduction to a Special Issue on Small and Medium-Sized Enterprises in the Global Economy. Small Business Economics, 9(1), 1-6. http://dx.doi.org/10.1023/A:1007945327618

Ahuja, G. (2000). Collaboration networks, structural holes, and innovation: A longitudinal study. Administrative Science Quarterly, 45(3), 425-455. http://dx.doi.org/10.2307/2667105

Akyol, A., \& Akehurst, G. (2003). An investigation of export performance variations related to corporate export market orientation. European Business Review, 15(1), 5-19. http://dx.doi.org/10.1108/09555340310455155

Aldrich, H. E., \& Fiol, C. M. (1994). Fools Rush in? The Institutional Context of Industry Creation. The Academy of Management Review, 19(1), 645-670. http://dx.doi.org/10.1007/978-3-540-48543-8_5

Aldrich, H. E., \& Martinez, M. (2010). Entrepreneurship as social construction: a multilevel evolutionary approach. In Z. J. Acs \& D. B. Audretsch (Eds.), Handbook of entrepreneurship research (pp. 387-427). New York: Springer.

Allen, T. J. (1977). Managing the Flow of Technology: Technology Transfer and the Dissemination of Technological Information within the $R \& D$ Organization. Cambridge, MA: MIT Press.

Aloulou, W., \& Fayolle, A. (2005). A Conceptual Approach of Entrepreneurial Orientation Within Small Busness Context. Journal of Enterprising Culture, 13(1), 21-45. http://dx.doi.org/10.1142/S0218495805000045

Analoui, F., \& Karami, A. (2003). Strategic Management in Small and Medium Enterprises. London: Thompson Learning.

Anderson, B. S., \& Eshima, Y. (2011). The influence of firm age and intangible resources on the relationship between entrepreneurial orientation and firm growth among Japanese SMEs. Journal of Business Venturing, 28(3), 413-429. http://dx.doi.org/10.1016/j.jbusvent.2011.10.001

Arregle, J. L., Hitt, M. A., Sirmon, D. G., \& Very, P. (2007). The Development of Organizational Social Capital: Attributes of Family Firms. Journal of Management Studies, 44(1), 73-95. http://dx.doi.org/10.1111/j.1467-6486.2007.00665.x

Audretsch, D. B., \& Keilbach, M. (2004). Does Entrepreneurship Capital Matter? Entrepreneurship Theory and Practice, 28(5), 419-429. http://dx.doi.org/10.1111/j.1540-6520.2004.00055.x

Avlonitis, G. J., \& Salavou, H. E. (2007). Entrepreneurial orientation of SMEs, product innovativeness, and performance. Journal of Business Research, 60(1), 566-575. http://dx.doi.org/10.1016/j.jbusres.2007.01.001

Bandura, A. (1977). Self-efficacy: toward a unifying theory of behavioral change. Psychological Review, 84(2), 191-215. http://dx.doi.org/10.1037/0033-295X.84.2.191

Baron, R. M., \& Kenny, D. A. (1986). The moderator-mediator variable distinction in social psychological research: Conceptual, strategic, and statistical considerations. Journal of Personality and Social Psychology, 51(6), 1173-1182. http://dx.doi.org/10.1037/0022-3514.51.6.1173

Batjargal, B. (2007). Internet entrepreneurship: social capital, human capital, and performance of internet ventures 
in China. Research Policy, 36(5), 605-618. http://dx.doi.org/10.1016/j.respol.2006.09.029

Becker, J. M., Klein, K., \& Wetzels, M. (2012). Hierarchical Latent Variable Models in PLS-SEM: Guidelines for Using Reflective-Formative Type Models. Long Range Planning, 45(5-6), 359-394. http://dx.doi.org/10.1016/j.lrp.2012.10.001

Brendle, M. (2001). Personality and company culture: Important contributions to innovation and a source of competitive advantage for small businesses. (Unpublished doctoral dissertation). Clemson University, Clemson.

Bullinger, H. J. (1999). Turbulent times require creative thinking: new European concepts in production management. International Journal of Production Economics, 60, 9-27. http://dx.doi.org/10.1016/S0925-5273(98)00127-3

Chandler, G. N., \& Hanks, S. H. (1994). Market attractiveness, resource-based capabilities, venture strategies, and venture performance. Journal of Business Venturing, 9(4), 331-349. http://dx.doi.org/10.1016/0883-9026(94)90011-6

Cohen, S., \& Kaimenakis, N. (2007). Intellectual capital and corporate performance in knowledge-intensive SMEs. The Learning Organization, 14(3), 241-262. http://dx.doi.org/10.1108/09696470710739417

Cooper, A. C., Gimeno-Gascon, F. J., \& Woo, C. Y. (1994). Initial human and financial capital as predictors of new venture performance. Journal of Business Venturing, 9(5), 371-395. http://dx.doi.org/10.1016/0883-9026(94)90013-2

Covin, J. G., \& Slevin, D. P. (1989). Empirical relationship among strategic posture environmental context variables, and new venture performance, Frontiers Entrepreneurship Research. Wellesley, MA: Babson College.

Covin, J. G., \& Slevin, D. P. (1990). New venture strategic posture, structure, and performance: An industry life

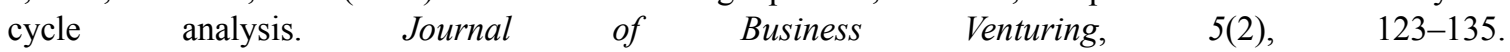
http://dx.doi.org/10.1016/0883-9026(90)90004-D

Cowling, M. (2004). The growth-profit nexus. Small Business Economics, 22(1), 1-9. http://dx.doi.org/10.1023/B: SBEJ. 0000011568.42714.c9

Craig, J. B., Pohjola, M., Kraus, S., \& Jensen, S. H. (2014). Exploring Relationships among Proactiveness, Risk-Taking and Innovation Output in Family and Non-Family Firms. Creativity and Innovation Management. http://dx.doi.org/10.1111/caim.12052

Davidsson, P. (1989). Continued entrepreneurship and small firm growth. Stockholm: School of Economics Stockholm.

Desouza, K. C., \& Awazu, Y. (2006). Knowledge management at SMEs: five peculiarities. Journal of knowledge Management, 10(1), 32-43. http://dx.doi.org/10.1108/136732706110650085

Francis, J., \& Collins-Dodd, C. (2000). The impact of firms' export orientation on the export performance of high-tech small and medium-sized enterprises. Journal of International Marketing, 8(3), 84-103. http://dx.doi.org/10.1509/jimk.8.3.84.19631

Frese, M., Brantjes, A., \& Hoorn, R. (2002). Psychological success factors of small scale businesses in Namibia: The roles of strategy process, entrepreneurial orientation and the environment. Journal of Developmental Entrepreneurship, 7(3), 259-282.

Gebreegziabher, K., \& Tadesse, T. (2014). Risk perception and management in smallholder dairy farming in Tigray, Northern Ethiopia. Journal of Risk Research, 17(3), 367-381. http://dx.doi.org/10.1080/13669877.2013.815648

Geletkanycz, M. A., \& Hambrick, D. C. (1997). The external ties of top executives: Implications for strategic choice and performance. Administrative Science Quarterly, 42(4), 654-681.

Granovetter, M. (1985). Economic action and social structure: the problem of embeddedness. Readings in Economic Sociology, 9(3), 63-68.

Henderson, R., \& Cockburn, I. (2006). Measuring competence? Exploring firm effects in pharmaceutical research. Strategic Management Journal, 15(S1), 63-84. http://dx.doi.org/10.1002/smj.4250150906

Hessels, S. J. A. (2008). International entrepreneurship: value creation across national borders. Rotterdam: Erasmus University Rotterdam. 
Hitt, M. A., Biermant, L., Shimizu, K., \& Kochhar, R. (2000). Direct and Moderating Effects of Human Capital on Strategy and Performance in Professional Service Firms: A Resource-Based Perspective. Academy of Management Journal, 44(1), 13-28. http://dx.doi.org/10.2307/3069334

Jaccard, J., \& Turrisi, R. (2003). Interaction effects in multiple regression. Newbury Park, CA: Sage Publications.

Jalali, A., Jaafar, M., \& Ramayah, T. (2014). Entrepreneurial orientation and performance: the interaction effect of customer capital. World Journal of Entrepreneurship, Management and Sustainable Development, 10(1), 48-68. http://dx.doi.org/10.1108/WJEMSD-05-2013-0030

Jalali, A., Jaafar, M., \& Thurasamy, R. (2013). Influence of entrepreneurial orientation on the financial performance: evidence from SMEs in Iran. Middle East Journal of Management, 1(2), 168-185. http://dx.doi.org/10.1504/MEJM.2013.057263

Kamalian, A. R., Rashki, D. M., \& Arbabi, M. L. (2011). Barriers to innovation among iranian SMEs. Asian Journal of Development Matters, 5(2), 251-265.

Katz, J. A., \& Brockhaus, R. H. (1993). Advances in entrepreneurship, firm emergence, and growth. Greenwich, CT: JAI Press.

Khatri, N. (2000). Managing human resource for competitive advantage: a study of companies in Singapore. International Journal of Human Resource Management, 11(2), 336-365. http://dx.doi.org/10.1080/095851900339909

Klyver, K., \& Schenkel, M. (2013). From Resource Access to Use: Exploring the Impact of Resource Combinations on Nascent Entrepreneurship. Journal of Small Business Management, 51(4), 539-556. http://dx.doi.org/10.1111/jsbm.12030

Kusar, J., Duhovnik, J., Grum, J., \& Starbek, M. (2004). How to reduce new product development time. Robotics and Computer-Integrated Manufacturing, 20(1), 1-15. http://dx.doi.org/10.1016/S0736-5845(03)00049-8

Lechner, C., \& Dowling, M. (2003). Firm networks: external relationships as sources for the growth and competitiveness of entrepreneurial firms. Entrepreneurship \& Regional Development, 15(1), 1-26. http://dx.doi.org/10.1080/08985620210159220

Lockett, A., Thompson, S., \& Morgenstern, U. (2009). The development of the resource-based view of the firm: A critical appraisal. International Journal of Management Reviews 11(1), 9-28. http://dx.doi.org/10.1111/j.1468-2370.2008.00252.x

Low, M. B., \& Abrahamson, E. (1997). Movements, bandwagons, and clones: Industry evolution and the entrepreneurial process. Journal of Business Venturing, 12(6), 435-457. http://dx.doi.org/10.1016/S0883-9026(97)00001-3

Lambert, D. M., \& Harrington, T. C. (1990). Measuring nonresponse bias in customer service mail surveys. Journal of Business Logistics, 11(2), 5-25.

Lumpkin, G. T., \& Dess, G. G. (1996). Clarifying the entrepreneurial orientation construct and linking it to performance. Academy of Management Review, 21(1), 135-172. http://dx.doi.org/10.5465/AMR.1996.9602161568

Lumpkin, G. T., \& Dess, G. G. (2001). Linking two dimensions of entrepreneurial orientation to firm performance: The moderating role of environment and industry life cycle. Journal of Business Venturing, 16(5), 429-451. http://dx.doi.org/10.1016/S0883-9026(00)00048-3

March, J. G. (1991). Exploration and exploitation in organizational learning. Organization Science, 2(1), 71-87. http://dx.doi.org/10.1287/orsc.2.1.71

Matoofi, A., \& Tajeddini, K. (2011). Effect of Market Orientation and Entrepreneurial Orientation on innovation: Evidence from Auto Parts Manufacturing in Iran. Journal of Management Research, 11(1), 20-30.

McCleland, D. (1961). The achieving society. Toronto: D. Van Nostrong.

McKiernan, P. (1997). Strategy past; strategy futures. Long Range Planning, 30(5), 790-798. http://dx.doi.org/10.1016/S0024-6301(97)00080-0

Mcmillan, I. C. (1983). The politics of new venture management. Harward Business Review, 61, 8-13

McGrath, R. G. (2001). Exploratory learning, innovative capacity and managerial oversight. Academy of 
Management Journal, 44(1), 118-131. http://dx.doi.org/10.2307/3069340

Meihami, B., Varmaghani, Z., \& Meihami, H. (2014). Role of Intellectual Capital on Firm Performance (Evidence from Iranian Companies). International Letters of Social and Humanistic Sciences, (1), 43-50.

Miller, D. (1983). The correlates of entrepreneurship in three types of firms. Management Science, 29(7), 770-791.

Naldi, L., Nordqvist, M., Sjöberg, K., \& Wiklund, J. (2007). Entrepreneurial orientation, risk taking, and performance in family firms. Family Business Review, 20(1), 33-47. http://dx.doi.org/10.1111/j.1741-6248.2007.00082.x

Peng, M. W., \& Luo, Y. (2000). Managerial ties and firm performance in a transition economy: The nature of a micro-macro link. Academy of Management Journal, 43(3), 486-501. http://dx.doi.org/10.2307/1556406

Perrigot, R., López-Fernández, B., \& Eroglu, S. (2013). Intangible Resources and Plural Form as Drivers of Franchise Internationalization: Examination within a Two-Country Perspective. Journal of Small Business Management, 51(4), 557-577. http://dx.doi.org/10.1111/jsbm.12006

Peteraf, M. A. (1993). The cornerstones of competitive advantage: a resource-based view. Strategic Management Journal, 14(3), 179-191. http://dx.doi.org/10.1002/smj.4250140303

Podolny, J. M. (1993). A status-based model of market competition. American Journal of Sociology, 98(4), 829-872.

Putnam, R. D. (2000). Bowling alone: The collapse and revival of American community. New York: Simon \& Schuster.

Rauch, A., Wiklund, J., Lumpkin, G. T., \& Frese, M. (2009). Entrepreneurial orientation and business performance: An assessment of past research and suggestions for the future. Entrepreneurship Theory and Practice, 33(3), 761-787. http://dx.doi.org/10.1111/j.1540-6520.2009.00308.x

Ray, G., Barney, J. B., \& Muhanna, W. A. (2004). Capabilities, business processes, and competitive advantage: choosing the dependent variable in empirical tests of the resource-based view. Strategic Management Journal, 25(1), 23-37. http://dx.doi.org/10.1002/smj.366

Robb, A. M., \& Robinson, D. T. (2014). The Capital Structure Decisions of New Firms. The Review of Financial Studies, 27(1), 153-179. http://dx.doi.org/10.1093/rfs/hhs072

Roxas, H. B., \& Chadee, D. (2012). A resource-based view of small export firms' social capital in a Southeast Asian country. Asian Academy of Management Journal, 16(2), 1-28.

Rwigema, H., \& Karungu, P. (1999). SMME development in Johannesburg's Southern Metropolitan Local Council: an assessment. Development Southern Africa, 16(1), 107-124. http://dx.doi.org/10.1080/03768359908440064

Sanayei, A., \& Rajabion, L. (2012). Critical successful factors contributing to e-commerce adoption among Iranian SMEs. International Journal of Information Science and Management (IJISM), 7(2), 57-65.

Segal, G., Borgia, D., \& Schoenfeld, J. (2005). The motivation to become an entrepreneur. International Journal of Entrepreneurial Behaviour \& Research, 11(1), 42-57. http://dx.doi.org/10.1108/13552550510580834

Smit, Y., \& Watkins, J. (2012). A literature review of small and medium enterprises (SME) risk management practices in South Africa. African Journal of Business Management, 6(21), 6324-6330.

Soininen, J., Puumalainen, K., Sjögrén, H., \& Syrjä, P. (2012). The impact of global economic crisis on SMEs: Does entrepreneurial orientation matter? Management Research Review, 35(10), 927-944. http://dx.doi.org/10.1108/01409171211272660

Stanley, L. L., \& Wisner, J. D. (2001). Service quality along the supply chain: implications for purchasing. Journal of Operations Management, 19(3), 287-306. http://dx.doi.org/10.1016/S0272-6963(00)00052-8

Starr, J. A., \& MacMillan, I. (1990). Resource cooptation via social contracting: Resource acquisition strategies for new ventures, Strategic Management Journal, 11(Summer), 79-92

Stuart, T. E., Hoang, H., \& Hybels, R. C. (1999). Interorganizational endorsements and the performance of entrepreneurial ventures. Administrative Science Quarterly, 44(2), 315-349. http://dx.doi.org/10.2307/2666998

Tajeddini, K., \& Mueller, S. L. (2009). Entrepreneurial characteristics in Switzerland and the UK: a comparative 
study of techno-entrepreneurs. Journal of International Entrepreneurship, 7(1), 1-25. http://dx.doi.org/10.1007/s10843-008-0028-4

Talebi, K., Tajeddin, M., Rastgar, A. A., \& Emami, A. (2012). Internationalization of SMEs and Organizational Factors in a Developing Country: A Case Study of ICT Industry of Iran. International Journal of Academic Research in Business \& Social Sciences, 2(12), 80-96.

Talebi, K., \& Tajeddin, M. (2011). The adoption of new and innovative knowledge by small and medium enterprises of Iran: Opportunities and constraints for growth. African Journal of Business Management, 5(1), 39-49. http://dx.doi.org/10.5897/AJBM10.366

Teece, D. J. (1986). Profiting from technological innovation: Implications for integration, collaboration, licensing and public policy. Research Policy, 15(6), 285-305. http://dx.doi.org/10.1016/0048-7333(86)90027-2

Teece, D. J. (2007). Explicating dynamic capabilities: the nature and microfoundations of (sustainable) enterprise performance. Strategic Management Journal, 28(13), 1319-1350. http://dx.doi.org/10.1002/smj.640

Terziovski, M. (2010). Innovation practice and its performance implications in small and medium enterprises (SMEs) in the manufacturing sector: a resource-based view. Strategic Management Journal, 31(8), 892-902. http://dx.doi.org/10.1002/smj.841

West, S. G., \& Aiken, L. S. (1991). Multiple regression: Testing and interpreting interactions. Newbury Park, CA: Sage Publications.

Wiklund, J., \& Shepherd, D. (2005). Entrepreneurial orientation and small business performance: a configurational approach. Journal of Business Venturing, 20(1), 71-91. http://dx.doi.org/10.1016/j.jbusvent.2004.01.001

Wong, K. Y., \& Aspinwall, E. (2005). An empirical study of the important factors for knowledge-management adoption in the SME sector. Journal of Knowledge Management, 9(3), 64-82. http://dx.doi.org/10.1108/13673270510602773

Wood, R., \& Bandura, A. (1989). Social cognitive theory of organizational management. Academy of Management Review, 14 (3), 361-384. doi:10.5465/AMR.1989.4279067

Zahra, S. A. (2010). Harvesting Family Firms' Organizational Social Capital: A Relational Perspective. Journal of Management Studies, 47(2), 345-366. http://dx.doi.org/10.1111/j.1467-6486.2009.00894.x

Zahra, S. A. (1996). Technology strategy and new venture performance: a study of corporate-sponsored and independent biotechnology ventures. Journal of Business Venturing, 11(4), 289-321. http://dx.doi.org/10.1016/0883-9026(95)00128-X

Zahra, S. A., \& Covin, J. G. (1995). Contextual influences on the corporate entrepreneurship-performance relationship: A longitudinal analysis. Journal of Business Venturing, 10(1), 43-58. http://dx.doi.org/10.1016/0883-9026(94)00004-E

Zhang, Y., \& Zhang, X. E. (2012). The effect of entrepreneurial orientation on business performance: A role of network capabilities in China. Journal of Chinese Entrepreneurship, 4(2), 132-142. doi:10.1108/17561391211242744

Zimmerman, M. A., \& Zeitz, G. J. (2002). Beyond survival: Achieving new venture growth by building legitimacy. Academy of Management Review, 27(3), 414-431. http://dx.doi.org/10.5465/AMR.2002.7389921

\section{Copyrights}

Copyright for this article is retained by the author(s), with first publication rights granted to the journal.

This is an open-access article distributed under the terms and conditions of the Creative Commons Attribution license (http://creativecommons.org/licenses/by/3.0/). 